\title{
ANOMALI SP BAWAH PERMUKAAN ZONA AIR ASIN DAN ZONA AIR TAWAR DI DESA MATA IE RANTO PEURELAK KABUPATEN ACEH TIMUR
}

\author{
Maulina Mawaddah ${ }^{{ }^{*}}$, Fajriani $^{1}$ \\ ${ }^{1}$ Program Studi Fisika, Fakultas Teknik, Universitas Samudra, Jalan. Prof Syarief Thayeb Meurandeh, Kota Langsa-Aceh, 24416, \\ Indonesia \\ *e-mail: Maulinamw98@gmail.com
}

\begin{abstract}
ABSTRAK
Telah dilakukan penelitian sebaran bawah permukaan zona air asin dan zona air tawar di Desa Mata Ie Kecamatan Ranto Peurelak Kabupaten Aceh Timur menggunakan metode Self-Potential dengan teknik Fixed-Based. Data SP diolah menggunakan Surfer 13 untuk memperoleh peta kontur isopotensial. Sebaran zona air tawar berada disebagian wilayah utara dengan nilai SP tinggi berkisar antara 24 $\mathrm{mV}$ sampai $30 \mathrm{mV}$ dan sebagian wilayah lainnya merupakan zona air asin dengan nilai SP rendah berkisar antara -2 $\mathrm{mV}$ sampai -4 mV. Nilai SP pada zona air asin cenderung rendah diperkirakan akibat dari jumlah akumulasi air tawar lebih besar dibandingkan dengan akumulasi air asin sehingga nilai Sp yang terukur tinggi. Hasil dari analisis uji DO dan pH membuktikan bahwa di daerah lokasi penelitian terdapat air asin dan air tawar.
\end{abstract}

Kata Kunci: Air Asin; Air Tawar; Self-Potential; Fixed-Based.

\section{ABSTRACT}

[Title: Determination of The Under Surface Distribution Of The Saltwater And Freshwater Zones Using SlefPotential Method In Mata Ie Ranto Peurelak East Aceh] Research on the subsurface distribution of the saltwater and freshwater zones in Mata Ie, Ranto Peurelak, East Aceh, has been carried out using the Self-Potential method with technique Fixed-Based. SP data is processed using Surfer 13 to obtain isopotential contour maps. The distribution of the freshwater zone in the northern part of the region with high SP values ranging from $24 \mathrm{mV}$ to $30 \mathrm{mV}$ and some other areas are salt water zones with low SP values ranging between $-2 \mathrm{mV}$ and -4 $\mathrm{mV}$. The SP value in the saltwater zone tends to be low estimated because the amount of accumulated fresh water being greater than the accumulation of salt water so that the measured SP value is high. The results of the DO and $\mathrm{pH}$ test analysis prove that in the study area there are saltwater and freshwater.

Keywords: Saltwater and Freshwater; Self-Potential; Fixed-Based.

\section{PENDAHULUAN}

Air salah satu kebutuhan yang sangat penting bagi kelangsungan hidup manusia. Salah satu jenis air adalah air tanah yang merupakan sumberdaya air yang sangat potensial untuk memenuhi kebutuhan manusia, kebutuhan rumah tangga, kebutuhan irigasi, dan kebutuhan industri (Andualem dkk, 2019).

Metode yang digunakan untuk mendeteksi keberadaan air tanah salah satunya adalah Metode Self-Potential (SP). Metode SP adalah suatu metode geofisika yang sederhana dan mudah. Namun, metode ini dapat bekerja dengan baik apabila digunakan untuk eksplorasi bawah permukaan dangkal pada kedalaman kurang dari 100 meter (Handoko dkk, 2016).

Beberapa penelitian menggunakan metode Self-Potential diantaranya, yaitu: Penelitian mengenai penyelidikan potensi air tanah yang dilakukan oleh Siswoyo (2018) di Desa Bono Kecamatan Pakel pada lahan pertanian dan berhasil mendapatkan informasi bahwa adanya formasi pasir kasar yang merupakan lapisan pembawa air (akuifer). Selain itu juga Vaidila (2015) melakukan penelitian di kawasan obyek wisata Guci tentang pendugaan reservoir panas bumi dan diprediksikan bahwa arah aliran fluida mengarah dari selatan menuju utara. Selanjutnya penelitian yang dilakukan oleh Diah (2017) tentang interpretasi persebaran mineral pasir besi di Desa Kapanjen menggunakan Metode Self-Potential, 
dimana pada penelitian tersebut digunakan 2 lintasan dan diperoleh bahwa pola persebaran mineral pasir besi tersebut sepanjang lintasan 1-2. Hasil dari beberapa penelitian tersebut membuktikan bahwa metode Slef-Potential dapat berfungsi dengan baik.

Di wilayah Aceh sebagian besar penduduk memanfaatkan air tanah sebagai pemasok air bersih, salah satu diantaranya wilayah Ranto Peurelak. Di Desa Mata Ie Kecamatan Ranto Peurelak Kabupaten Aceh Timur daerah dataran tinggi yang memiliki kualitas air asin dan sulit mendapatkan air layak konsumsi. Desa Mata Ie terdiri dari 5 (lima) dusun, 1 (satu) dusun yang memiliki air asin dan air tawar, 4 (empat) dusun lainnya memiliki air asin. Akses jalan yang cukup jauh dari perkotaan dengan kondisi jalan yang kurang baik serta tidak adanya layanan jaringan PDAM ke Desa Mata Ie Kecamatan Ranto Peurelak semakin menyulitkan masyarakat sekitar dalam memperoleh air bersih.

Berdasarkan permasalahan akan kebutuhan air bersih di Desa Mata Ie, maka dalam skripsi ini penulis mengambil judul anomali SP bawah permukaan zona air asin dan zona air tawar di Desa Mata Ie Ranto Peurelak Kabupaten Aceh Timur. Penelitian ini nantinya diharapkan dapat menjadi solusi permasalahan masyarakat Desa Mata Ie akan ketersediaan air bersih.

\section{METODE}

\section{Waktu dan Tempat Penelitian}

Penelitian ini dilakukan di Desa Mata Ie, Kecamatan Ranto Peurelak, Kabupaten Aceh Timur. Penelitian tersebut dilakukan pada tanggal 29 September 2020 sampai 01 Oktober 2020. Lokasi pengambilan data dapat dilihat pada Gambar di bawah ini:

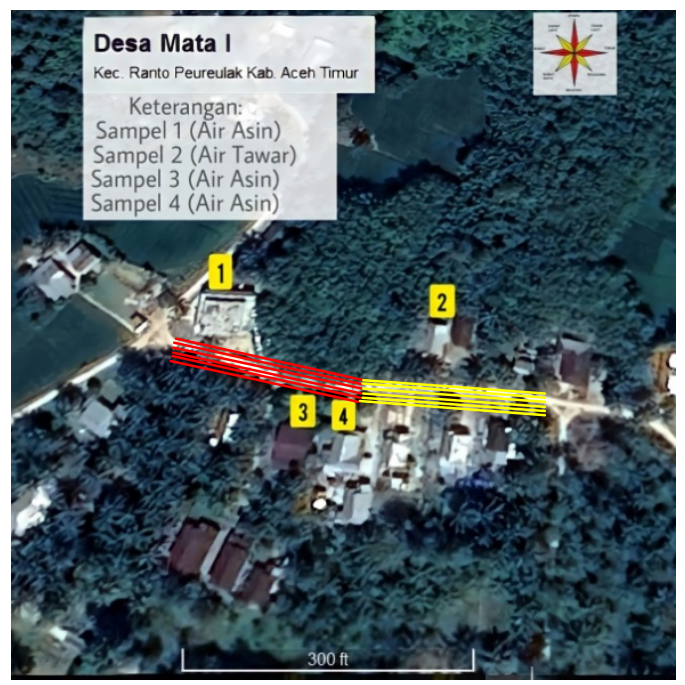

Gambar 1. Lokasi pengambilan data dengan lintasan pengukuran horizontal dan lokasi pengambilan sampel air

\section{Alat dan Bahan}

Alat dan bahan yang digunakan yaitu Porouspot, Multimeter, GPS (Global Positioning System), Meteran, Linggis, Penjepit Buaya, Kabel Listrik, Disollved Oxygen (DO) meter, pH meter, Larutan $\mathrm{CuSO}_{4}$, dan Air.

\section{Tahapan Proses Penelitian}

Tahapan Proses Penelitian meliputi langkahlangkah berikut:

Survei Lapangan, tahap ini merupakan tahap awal yaitu pemilihan lokasi penelitian. Pada tahap ini juga ditentukan arah dan panjang lintasan serta lebar spasi untuk lintasan pada masing-masing lokasi pengambilan data.

Kalibrasi alat, merupakan suatu langkah yang bertujuan untuk memperoleh data lapangan yang baik. Kalibrasi alat dapat dilakukan dengan menanam kedua elektroda ke dalam tanah dengan jarak yang dekat (sekitar $10 \mathrm{~cm}$ ). Beda potensial yang diukur harus lebih kecil atau sama dengan 2 milivolt (Arisalwadi, dkk 2020).

Pengambilan data pengukuran menggunakan teknik Fixed-Based, yaitu dua buah elektroda porous pot ditanam pada titik lintasan yang ditentukan. Salah satu elektroda berada pada satu titik yang tetap disebut titik referensi. Elektroda yang lain kemudian dipindah-pindahkan menjauhi titik referensi untuk setiap pengukuran dengan konfigurasi fixed-Based seperti pada Gambar 2.

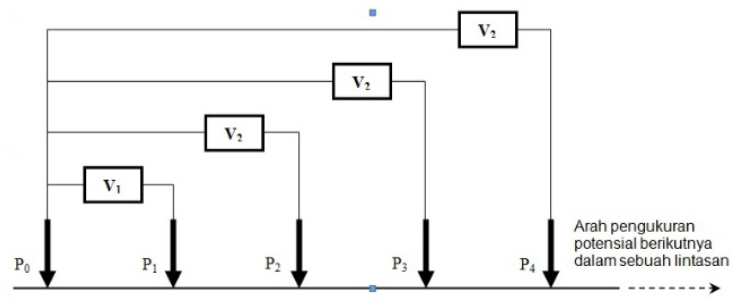

Gambar 2. Teknik Pengukuran data dalam metode Self-Potential dengan konfigurasi Fixed Based (Sehah dan Raharjo, 2011).

\section{Pengolahan Data}

a. Pengolahan Data Self-Potential Pada setiap titik ukur dilapangan, data yang diperoleh adalah nilai potensial atau tegangan antara dua buat elektroda yang terbaca pada multimeter digital. Data potensial ini belum menunjukkan nilai 
potensial dititik ukur tersebut, jika pengukuran diulang pada waktu berlainan maka akan terjadi perbedaan nilai potensial disuatu titik. Maka dari itu, hasil pengukuran data SP harus dikoreksi, yaitu dengan koreksi harian. Kemudian setelah data SP dikoreksi dapat diasumsikan sebagai data SP.

b. Melakukan pengujian sampel air sumur warga yang terdapat di daerah lokasi penelitian untuk membuktikan bahwa di daerah tersebut terdapat air asin dan air tawar.

\section{HASIL DAN PEMBAHASAN \\ HASIL DAN PENGOLAHAN DATA}

Jumlah titik pengukuran di daerah penelitian adalah 817 titik dari 12 lintasan dengan jarak antar titik 1 meter. Dari hasil pengukuran SP di lapangan dapat dilihat data rentang nilai potensial listrik setiap lintasan pada Tabel 1.

Tabel 1. Data rentang nilai potensial listrik setiap Lintasan

\begin{tabular}{|c|c|}
\hline Lintasan & Rentang nilai SP (mV) \\
\hline Pertama & $-6-30$ \\
\hline Kedua & $-7-19$ \\
\hline Ketiga & $-10-22$ \\
\hline Keempat & $-3-25$ \\
\hline Kelima & $-8-12$ \\
\hline Keenam & $-2,5-8$ \\
\hline Ketujuh & $-1,5-11,5$ \\
\hline Kedelapan & $-1,5-12$ \\
\hline Kesembilan & $-4-9,5$ \\
\hline Kesepuluh & $-5,2-0,2$ \\
\hline Kesebelas & $-2-0,6$ \\
\hline Keduabelas & $-1,8-3,4$ \\
\hline
\end{tabular}

Tabel 1 di atas menunjukkan bahwa nilai SP terendah terdapat pada lintasan ketiga yaitu -10-22 $\mathrm{mV}$, sedangkan nilai SP tertinggi terdapat pada lintasan ketujuh yaitu -1,5-11,5 mV.

\section{Analisis Uji DO dan pH}

Sebagian besar penduduk di sekitar lokasi penelitian menggunakan air sumur bor untuk kebutuhan sehari-hari, tetapi tidak semua air sumur bor di lokasi penelitian layak digunakan karena ada sebagian air sumur bor asin dan sebagian air sumur bor tawar. Dalam penelitian ini selain melakukan penelitian tentang sebaran zona air asin dan zona air tawar menggunakan metode self-potential, penulis juga melakukan pengujian parameter DO (Dissolved
Oxygen) dan $\mathrm{pH}$ pada air sumur warga di sekitar lokasi penelitian. Uji DO dan $\mathrm{pH}$ digunakan untuk membuktikan bahwa di daerah penelitian ini kandungan air bawah tanahnya ada yang asin dan ada yang tawar. sampel air sumur dapat dilihat pada Gambar 3.

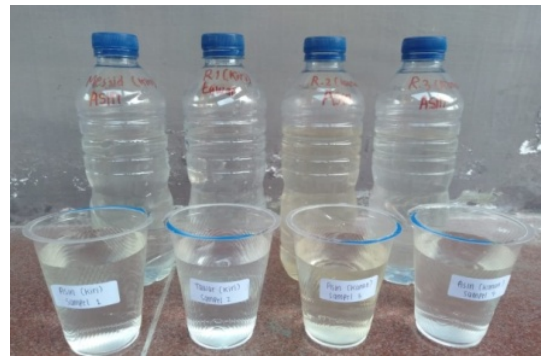

Gambar 3. Sampel air di sekitar lokasi penelitian

Hasil pengujian DO dan $\mathrm{pH}$ air sumur Desa Mata Ie, Kecamatan Ranto Peurelak, dapat dilihat pada Tabel 2. Uji kadar oksigen terlarut (DO) yang diperoleh Permenkes RI No. 429 dengan kadar maksimum yaitu berkisar dari 7 sampai 14 mg/L (Yulivarta, 2019).

Tabel 2. Hasil pengujian air sumur warga

\begin{tabular}{|c|c|c|c|c|c|c|}
\hline $\mathrm{No}$ & Parameter & \multicolumn{4}{|c|}{ Hasil Uji Air Sumur } & Satuan \\
\hline & & 1 & 2 & 3 & 4 & \\
\hline 1 & $\mathrm{DO}$ & 2,6 & 1,8 & 3,1 & 2,6 & $\mathrm{mg} / \mathrm{L}$ \\
\hline 2 & $\mathrm{pH}$ & 6,5 & 7,8 & 6,0 & 6,2 & - \\
\hline
\end{tabular}

Tabel 2 di atas menunjukkan bahwa hasil pengukuran nilai DO dari sampel air sumur warga sangat rendah. Kandungan oksigen terlarut pada sumber air sumur disekitar lokasi penelitian bervariasi, berkisar antara 1,8-3,1 mg/L. Nilai DO rendah memiliki daya hantar listrik yang tinggi karena air tersebut mengandung logam atau $\mathrm{NaCl}$ sehingga makin tinggi daya hantar listrik dalam air, maka air akan terasa payau sampai asin (Mukarromah, 2016). Data ini sesuai dengan yang ada di lapangan bahwa di daerah ini terdapat air tanah yang mengandung garam mineral sehingga di daerah ini air tanah memiliki rasa yang asin.

Nilai pH yang dihasilkan pada masing-masing sampel air sumur dilokasi penelitian yaitu kisaran 6,0-7,8. Nilai pH tertinggi sebesar 7,8 pada air sumur tawar, sedangkan nilai $\mathrm{pH}$ terendah sebesar 6,0 pada air sumur asin. Hasil pengukuran menunjukkan bahwa sampel pada air asin bersifat asam dan sampel air tawar bersifat basa. $\mathrm{pH}$ netral untuk air murni adalah 7, jika dibawah 7 maka bersifat asam dan jika diatas 7 maka bersifat basa, 
sehingga air tersebut tidak layak untuk digunakan (Zulius, 2017).

\section{Analisis Peta Kontur Isopotensial}

Berdasarkan hasil pengukuran dilapangan diperoleh data nilai beda potensial listrik dari keduabelas lintasan, selanjutnya dilakukan interpretasi secara kualitatif. Data tersebut dikoreksi terlebih dahulu, kemudian hasil SP terkoreksi diolah dengan menggunakan software surfer 13 untuk mendapatkan peta kontur isopotensial. Berdasarkan peta kontur tersebut, maka dapat dilihat anomali SP dari seluruh lintasan pada Gambar 4.

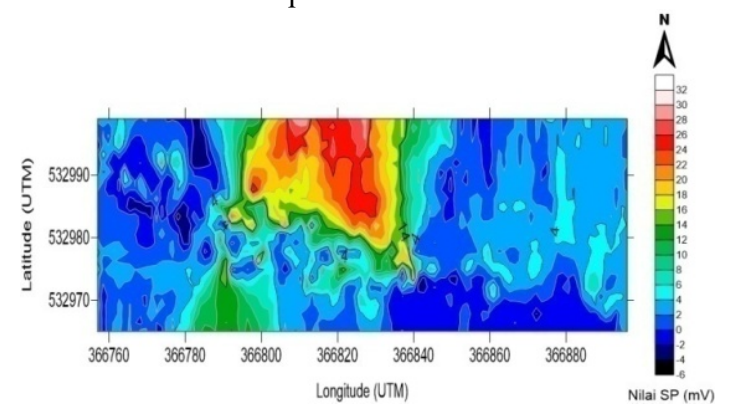

Gambar 4. Peta Kontur Isopotensial

Berdasarkan peta kontur isopotensial pada Gambar 4 dapat diketahui nilai SP berkisar antara -6 $\mathrm{mV}$ sampai $32 \mathrm{mV}$. Nilai potensial tinggi berada di bagian Utara daerah penelitian yang merupakan zona air tawar, sedangkan nilai potensial yang dominan rendah ditemukan di bagian Barat dan Timur daerah penelitian dengan nilai SP sebesar $-2 \mathrm{mV}$ sampai -6 $\mathrm{mV}$ yang merupakan zona air asin. Pada zona akumulasi air tawar didapatkan nilai SP tinggi berkisar antara $24 \mathrm{mV}$ sampai $32 \mathrm{mV}$, karena lokasi penelitian termasuk ke dalam jenis batuan pasir dan lumpur maka dapat diperkirakan bahwa di posisi Utara daerah penelitian yang memiliki nilai SP tinggi dominan tersusun dari lapisan batuan lumpur. Hal ini sesuai dengan hasil penelitian Ferial yang menyatakan bahwa nilai resistivitas rendah 23,0 Ohm-meter adalah lapisan batuan lumpur. Maka dapat diperkirakan juga bahwa lokasi penelitian yang memiliki nilai SP rendah berkisar antara $-2 \mathrm{mV}$ sampai - $6 \mathrm{mV}$ dominan tersusun dari lapisan batuan pasir memiliki konduktivitas tinggi yaitu 879 Ohmmeter (Ferial dkk, 2019). Untuk lebih jelasnya hasil pengukuran di lapangan dapat dilihat pada Gambar 5 di bawah ini:

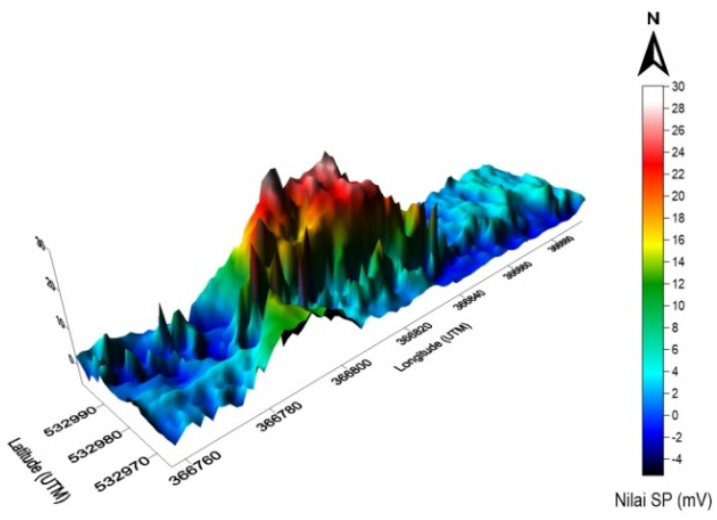

Gambar 5. Peta Kontur Isopotensial hasil pengukuran 3D

Gambar 5 di atas merupakan peta kontur isopotensial dalam bentuk 3D. Dari Gambar di atas dapat diketahui bahwa wilayah dengan puncak yang terlihat mewakili nilai SP di daerah penelitian, dimana puncak tertinggi mengindikasikan zona akumulasi air dengan jumlah yang banyak. Nilai potensial listrik tersebut berada di bagian utara dan sekitar lokasi penelitian diperkirakan sebagai zona air tawar.

\section{KESIMPULAN DAN SARAN}

Sebaran anomali SP di zona air asin dan air tawar tersebar dari bagian barat, selatan dan timur yang mempunyai nilai SP rendah berkisar antara -2 $\mathrm{mV}$ sampai $-6 \mathrm{mV}$, sedangkan di bagian Utara yang mempunyai nilai SP tinggi berkisar antara $24 \mathrm{mV}$ sampai $30 \mathrm{mV}$.

Pada daerah penelitian dengan nilai SP tinggi menunjukkan adanya air tawar yang berada di sebelah Utara lokasi penelitian. Nilai SP tinggi pada air tawar diperkirakan karena adanya akumulasi air tawar di lokasi tersebut dalam jumlah relatif besar.

\section{DAFTAR PUSTAKA}

Andualem, T. G., \& Demeke, G. G. (2019). Groundwater potential assessment using GIS and remote sensing: A case study of Guna tana landscape, upper blue Nile Basin, Ethiopia. Journal of Hydrology: Regional Studies, 24(June), 100610. https://doi.org/10.1016/j.ejrh.2019.10061 0 .

Arisalwadi, M., Cahyani, R. S., Septiana, A. R., Rahmania, \& Sastrawan, F. D. (2020). Aplikasi Metode Self-Potential untuk Pemetaan Bawah Permukaan di Area Kampus ITK. Indonesian Physical Review, 3(3), 1-8.

Diah, S., Febriani, A., \& Daniyati, R. (2017). Interpretasi Persebaran Mineral Pasir Besi 
Menggunakan Metode SP ( Self Potential ) di Desa Kepanjen. Seminar Nasional Hasil Penelitian 2017, (December 2017), 296-299.

Ferial dkk, (2019) Identifikasi Sebaran Mineral Bijih Besi dengan Menggunakan Metode Resistivitas dan Induced (IP) di Kecamatan Muara Uya, Kabupaten Tabalong, Provinsi Kalimantan Selatan. Jurnal Geosains Kutai Basin,2(2), 1-9.

Handoko, A. W., Darsono, D., \& Darmanto, D. (2016). Aplikasi Metode Self Potential untuk Pemetaan Sebaran Lindi di Wilayah Tempat Pembuangan Akhir (TPA) Putri Cempo Surakarta. Indonesian Journal of Applied Physics, 6(01), 13 .

https://doi.org/10.13507/ijap.v6i01.1792.

Mukarromah R. (2016). Analisis Sifat Fisis Kualitas Air Di Mata Air Sumber Asem Dusun Kalijeruk, Desa Siwuran, Kecamatan Garung, Kabupaten Wonosobo, Unnes Physic Journal, 5(1), 40-45.

Sehah dan Raharjo, S. . (2011). Survei Metode Self Potential Menggunakan Elektroda Pot Berpori Untuk Mendeteksi Aliran Fluida Panas Bawah Permukaan Di Kawasan BatuRaden Kabupaten Banyumas Jawa Tengah. Jurnal Fisika FLUX, 8(61), 7-21.

Siswoyo, H., \& Dkk. (2018). Penyelidikan Potensi Air Tanah pada Lahan Pertanian di Desa Bono Kecamatan Pakel Kabupaten Tulungagung dengan Menggunakan Metode Potensial Diri. Dinamika Rekayasa, 14(2), 112-118. https://doi.org/10.20884/1.dr.2018.14.2.2 19.

Vaidila, N., Supriyadi, \& Linuwih, S. (2015). Penentuan Arah Fluida Panas Bawah Permukaan di Obyek Wisata Guci Menggunakah Metode Self Potential. Unnes Physics Journal, 4(2), 1-8. Retrieved from https://journal.unnes.ac.id/sju/index.php/u $\mathrm{pj} / \mathrm{article} / \mathrm{view} / 8897$.

Yulivarta, A. P., Waluyo, J., \& Iqbal, M. (2019). Hubungan Kualitas Biologi, Kimia, Fisika Air Sumur Dengan Kepadatan Penduduk Di Kabupaten Jember. Saintifika, 21(2), 35-47.

Zulius, A. (2017). Rancang Bangun Monitoring pH Air Menggunakan Soil Moisture Sensor di SMK N 1 Tebing Tinggi Kabupaten Empat Lawang. Jusikom, 2(1), 37-43. 